\title{
Peripheral Venous Air Embolism in a Pregnancy (Case Report)
}

\author{
Lüitfiye Pirbudak ${ }^{1 *}$, Neslihan Bayramoğlu Tepe ${ }^{2}$, Yusuf Emeli ${ }^{1}$ and Ergün Mendeş \\ ${ }^{1}$ Department of Anaesthesiology and Reanimation, University of Gaziantep, Turkey, \\ ${ }^{2}$ Department of Obstetrics and Gynaecology, University of Gaziantep, Turkey,
}

Submission: April 05, 2018; Published: May 25, 2018

*Corresponding author: Lütfiye pirbudak, Department of Anaesthesiology, Division of Algology, Medical School, University of Gaziantep, Gaziantep, Turkey; Email: lutfiyep@hotmail.com

\begin{abstract}
Air embolism can occur in many medical surgical situations. Venous air embolism is often lethal when it enters to the venous circulation rapidly. Massive air embolism is usually diagnosed clinically with sudden hemodynamic deterioration. In this case report, the importance of $\mathrm{ETCO}_{2}$ monitoring in the treatment of pregnant patients with peripheral venous embolism (PVE) has been discussed.

Keywords: Venous air embolism; Pregnant; $\mathrm{ETCO}_{2}$; Hemodynamic Deterioration; Significant Morbidity; Venous Circulation; Pulmoner Venous Embolism; Sefazolin; Antibiotic Treatment; Dizziness; Dyspnea; Electrocardiography; Sinus Bradycardia; Blurred Vision; Swelling; Nasal capnography; Tachypnea Perfusator Systems; Serum sets; Computerized Tomography; Echocardiography; respiratory distress

Abbreviations: PVE: Pulmoner Venous Embolism; CT: Computerized Tomography; TOE: Transesophageal Echocardiography; VAE: Venous Air Embolisation
\end{abstract}

\section{Introduction}

Air embolism can occur in many medical surgical situations. Venous air embolism is often lethal when it enters to the venous circulation rapidly. It can cause significant morbidity when it is passed to systemic arterial circulation. Massive air embolism is usually diagnosed clinically with sudden hemodynamic deterioration [1]. In this case report, the importance of ETCO $_{2}$ monitoring in the treatment of pregnant patients with pulmoner venous embolism (PVE) has been discussed.

\section{Case Report}

The patient was a 30-years-old, 17 week first pregnancy woman with no known additional disease and no active problems in follow-up. While the patient was using sefazolin (İespor®) $500 \mathrm{mg}$ due to infectious influenza, she applied to another emergency service on the 4 th day of treatment. A venous vascular access was opened to receive antibiotic treatment in $100 \mathrm{cc} 0.9 \% \mathrm{NaCl}$. Approximately 1 minute after the solution begins to be given to the patient; dizziness, dyspnea and loss of consciousness presented in the patient. On the controls, it was noticed that there was air in the settee. Promptly, the patient was given a supine position and the patient's blood pressure was $70 / 30 \mathrm{mmHg}$ with spontaneous breathing, which was a positive light reflex. Electrocardiography detected sinus bradycardia. A new venous vascular access was opened to the patient for fluid replacement and $100 \% \mathrm{O}_{2}$ therapy was given. Approximately 5 minutes later, she regained consciousness and the patient's blood pressure was measured $90 / 50 \mathrm{mmHg}$. The patient described blurred vision and dyspnea. The systolic function of the patient was normal, valve movements were natural, and EF is $60 \%$ on ECHO. Fetal heart rate was positive under USG control and no additional distress was observed. In case of consultation with cardiovascular surgeon, he was not considered a massive embolism since no heat change, swelling, diameter difference was detected in both legs. Since the patient was pregnant, no radiation-containing examinations were performed. Eco was normal but clinic was significant.

At the end of the third day, the patient was admitted to our polyclinic with ongoing dyspnea and tachypnea. The patient underwent end-tidal $\mathrm{CO}_{2}$ measurement with an nasal capnography device and found to be $26 \mathrm{~mm} / \mathrm{Hg} ; \mathrm{SPO}_{2}$, measured at $96 \mathrm{~mm} / \mathrm{Hg}$. After three days of follow-up, $100 \% \mathrm{O}_{2}$ therapy and fluid replacement were performed at regular intervals. At the end of the third day ET- $\mathrm{CO}_{2}$ was measured $32 \mathrm{~mm} / \mathrm{Hg}, \mathrm{SPO}_{2}$ was measured at $98 \mathrm{~mm} / \mathrm{Hg}$. Dyspnea decreased significantly at the end of 3 days. Blurred vision was completely improved. 


\section{Discussion}

Peripheral venous air embolism is rare but can result in serious complications. Possible sources for air embolism are perfusator systems, serum sets, air in the injector which is not evacuated during intravenous drug injection.It is reported that the caesarean case which depends on in anesthesia, the usage of closed loop/circuit/cycle within in a short period high-power air interference is resulted death [2]. In computerized tomography (CT), a case was reported in which carelessly antecubital injection of $150 \mathrm{ml}$ air was performed during contrast medium injection [1]. Generally, in the venous system a small amount of air can be absorbed spontaneously, but when a large amount of air crosses over the systemic circulation rapidly, this can cause significant morbidity and mortality. Fatal air volume is defined as $200-300 \mathrm{~mL}$ or $3-5 \mathrm{~mL} / \mathrm{kg}$ for adults in case reports, while air collection rate is also important $[3,4]$. In this case, in the case of pulmonary venous air embolism which may be encountered during routine peripheral venous interventions, the symptoms and end-tidal $\mathrm{CO}_{2}$ pressure were guided by the fact that patient was a pregnant.

Clinical indicators are late findings of pulmoner venous air embolism and these are not specific. Monitors are more sensitive but can give false positives. End-tidal capnography and precordial doppler are the most sensitive combination. But none of these are specific to Venous air embolisation (VAE). Transesophageal echocardiography (TOE), is the most sensitive and specific monitor [5]. Nasal $\mathrm{ETCO}_{2}$ level was considered in the diagnosis and treatment of our patient. On the $3^{\text {rd }}$ day of $100 \%$ oxygen treatment, it was determined that $\mathrm{O}_{2}$ treatment was sufficient when $\mathrm{ETCO}_{2}$ level was reached normal limit. $\mathrm{ETCO}_{2}$ is a useful tool for detecting VAE because of its widespread use in the operating room. A change in $\mathrm{ETCO}_{2}$ is considered significant and can be determined if it reduces $0.2 \%$ of baseline (53) or $2 \mathrm{~mm} / \mathrm{Hg}$ (57) [6]. Critical care doctors need to be aware of the symptoms of air embolism and be ready to implement possible therapeutic maneuvers [1]. Peripheral air embolism should be treated with $100 \% \mathrm{O}_{2}$, fluid infusion and vasopressor should be given to correct hypotension. Durant's maneuver (Left-lateral decubitus, up-down positioning) can also be applied [1]. Although VAE is uncommon complication, it is potentially life-threatening and requires prevention and early detection. It should be keep in mind that medical personnel should be trained better, especially to improve the training of injector technicians is crucial because of to prevent this preventable complication.

\section{Conclusion}

Air embolism is a rare complication. It is potentially lifethreatening and should be prevented and detected early. Patients should be suspected if they have a sudden onset of respiratory distress and / or are experiencing a neurological event in a known risk factor setting. We believe that $\mathrm{ETCO}_{2}$ measurement is a simple and effective method in the diagnosis and treatment of pregnant patients. We recommend that $100 \% \mathrm{O}_{2}$ treatment should be continued until $\mathrm{ETCO}_{2}$ normalizes.

\section{References}

1. Lanfranco J, Romero Legro I, Freire AX, Nearing K, Ratnakant S (2017) Pulmonary Air Embolism: An Infrequent Complication in the Radiology Suite. Am J Case Rep 18: 80-4.

2. Bakan M, Topuz U, Esen A, Basaranoglu G, Ozturk E (2013) Inadvertent venous air embolism during cesarean section: Collapsible intravenous fluid bags without self-sealing outlet have risks. Case report. Braz J Anesthesiol 63(4): 362-365.

3. Mirski MA, Lele AV, Fitzsimmons L, Toung TJ (2017) Diagnosis and treatment of vascular air embolism. Anesthesiology 106(1): 164-177.

4. Toung TJ, Rossberg MI, Hutchins GM (2001) Volume of air in a lethal venous air embolism. Anesthesiology 94(2): 360-361.

5. Chang JL, Albin MS, Bunegin L, Hung TK (1980) Analysis and comparison of venous air embolism detection methods. Neurosurgery $7(2): 135-41$.

6. Losasso TJ, Black S, Muzzi DA, Michenfelder JD, Cucchiara RF (1992) Detection and hemodynamic consequences of venous air embolism. Does nitrous oxide make a difference? Anesthesiology 77(1): 148-152.

Your next submission with Juniper Publishers
will reach you the below assets
- Quality Editorial service
- Swift Peer Review
- Reprints availability
- E-prints Service
- Manuscript Podcast for convenient understanding
- Global attainment for your research
- Manuscript accessibility in different formats
( Pdf, E-pub, Full Text, Audio)
- Unceasing customer service
Track the below URL for one-step submission
https://juniperpublishers.com/online-submission.php

